\title{
The Equal Protection Clause and Exclusionary Zoning After Valtierra and Dandridge
}

A number of federal and state courts have recently ordered changes in local land-use regulations on equal protection and due process grounds. ${ }^{1}$ The decisions are a response to the burdensome inequities produced and perpetuated by many municipal land-use schemes, ${ }^{2}$ and have created speculation that court action might eliminate or restrict zoning practices which discriminate against racial minorities and the poor. ${ }^{3}$ The Supreme Court's recent decisions in Dandridge $v$. Williams' and James $v$. Valtierra, ${ }^{5}$ however, have been interpreted by many as a termination of this development-as an indication that the Court will not expand equal protection doctrine to reach exclusionary zoning. ${ }^{\circ}$ Dandridge upheld the constitutionality of a Maryland statute which placed a maximum limit on the amount of aid a family could collect regardless of the number of children in the family. Valtierra held that Article XXXIV of the California State Constitution, which required a referendum before public housing could be built in a community, did not violate the equal protection clause. ${ }^{7}$ This Note will argue, however, that there are satisfactory constitutional rationales for overturning exclusionary zoning statutes left unaffected by these decisions. Courts should distinguish Valtierra and Dandridge and stringently

1. See, e.g., Dailey v. City of Lawton, 425 F.2d 1037 (10th Cir. 1970); Southern Alameda Spanish Speaking Organization v. Union City [hereinafter cited as SASSO]. 424 F.2d 291 (9th Cir. 1970); Kennedy Park Homes Ass'n v. City of Lacliawanna, 318 F. Supp. 669 (W.D.N.Y. 1970), aff'd, 436 F.2d 108 (2d Cir. 1970), cert. denied, 401 U.S. 1010 (1971); Oakwood at Madison, Inc. v. Township of Mrdison, 117 N.J. Super. 11, _ A.2d (1971); Appeal of Girsh, $447 \mathrm{~Pa} .237 ; 263$ A.2d 395 (1970); Concord Twp. Appeal, 439 Pa. 466, 268 A.2d 765 (1970).

2. See, e.g., 425 F.2d at 1037-1939; 318 F. Supp. at 697; 447 Pa. at 473-76, 268 A.2d at 768-69.

3. See Note, Exclusionary Zoning and Equal Protection, 84 HaRv. L. REv. 1645 (1971); Note, Zoning: Closing the Economic Gap, 43 TEMrLe L.Q. 347 (1970).

4. 397 U.S. 471 (I970).

5. 402 U.S. $137(1971)$.

6. Interview with Herbert Franklin of the National Urban Coalition, Nov. 8, 1971. Mr. Franklin is the coordinator of the Exclusionary Land Use Clearing House Conferences held quarterly at the National Urban Coalition offices in Washington, D.C. Mfr. Franklin reports that some of the chief strategists in the exclusionary zoning ficld beliete that Valtierra and Dandridge indicate that constitutional challenges to exclusionary landuse practices are doomed to failure. Attorney General John Afitchell has indicated that he believes that Valtierra signals that the Court will not move to end exclusionary zoning. Mitchell Scorns Economic Integration of the Suburbs as Contrary to High Court, The Courier-Journal and Times (Louisville, Ky.), June 6, 1971, at A-4, col. 1.

7. Article XXXIV applies only to publicly financed low-cost housing, not to other types of government projects or to housing for any group other than low-income families. 402 U.S. at 139. Moreover, referenda are required for only a few other types of state action in California. Id. at 142. 
scrutinize zoning statutes that exclude racial minorities or the poor from access to housing within a community.

\section{The Problem and the Need for Judicial Response}

Zoning is exclusionary when the zoning laws of a community seriously impede or absolutely prevent the construction of low-cost housing. Suburban zoning laws often exclude high density, low-cost apartments and trailer parks. This effectively leaves metropolitan area poor and moderate-income families ${ }^{8}$ no alternative but to live in the central cities. ${ }^{9}$ At the same time that suburban zoning laws, building codes, and other land-use barriers prevent these families from moving out of the central cities, most of the new clerical, unskilled, and semiskilled jobs in metropolitan areas are being created in the suburbs. ${ }^{10}$ The low- and moderate-income families who live in the central cities are thus segregated by land-use regulations from easy access to the most rapidly growing job markets.

Another consequence is relative depletion of central city tax bases, which must support locally funded services for the majority of the

8. The definitions of "poverty" and "moderate income level" are much in disputg. D. Hamilton, A PRimer on THE Economics of PoverTy 22.33 (1968). But for purposes of this Note the Social Security Poverty Lines of $\$ 3,130$ for a non-farm family of four and $\$ 5,090$ for a non-farm family of seven may be accepted. Id. at 31 . Moderate income family will be defined as those families with an income below $\$ 4,005$ for a nonfarm family of four or below $\$ 6,395$ for a non-farm family of seven. Id. at 31. This meatis that approximately one fourth of all families living in Standard Metropolitan Statistical Areas are of low or moderate income. H. SHEPPARD, Poverty AND WEALTII IN AMEkICA 8 (1970).

9. See Report of the National Advisory Commission on Civil Disorders 22 (Bantam ed. 1968) [hereinafter cited as KERNER REPORT]:

To continue present [land use] policies is to make permanent the division of our country into two societies; one, largely Negro and poor, located in the central cities; the other, predominantly white and affluent, located in the suburbs ....

Of course, some suburbs have substantial numbers of low-income families. There are, for example 180,000 poor families in the thirteen suburban counties ringing New York City. Blumenthal, Suburban Poor Suffer Amid Environment of Affluence, N.X. Times, May 26, 1968, at 1, col. 4. However, the central cities contain a much higher proportion of the poor than do the suburbs taken as a whole. See Schnore, The Socio-Economic Status of Cities and Suburbs, AM. Sociological REV. 76 (1963). These differences do not disappear with time. Rather, the socio-economic character of a suburb apperars to maintain itself over long periods. See, e.g., Brazer, Economic and Social Disparilies be. tween Central Cities and Their Suburbs, 43 LAND Econ. 294 (1967); Farley, Stuburban Persistence, 29 AM. Sociological Rev. 38 (1964).

10. See Kain, The Distribution and Movement of Jobs and Industry, in THE METno. POLITAN ENIGMA (J. Wilson ed. 1967); KERNER REPORT, supra note 9, at 406.07; Shipler, Lawsuit to Challenge Zoning as Discriminating Against Poor, N.Y. Times, Junc 29, 1969, at 39, col. 1; Darnton, Big Business Draws Service Industries to Suburban Areas, N.X. Times, Feb. 22, 1971, at 1, col. 5, and 19, col. 1; Reeves, Loss of Major Companies in Cily Conceded by Patton, N.Y. Times, Feb. 5, 1971, at 33, col. 8.

Township of Mahwah, Docket No. A2592-70 (Super. Ct. of N.J., App. Div. 1971), a case currently pending in the Superior Court of Bergen County, N.J., involves the con. tention that a community must consider changing job patterns when making and ap. plying its zoning laws. 
metropolitan area poor and near poor, ${ }^{11}$ while exclusionary zoning keeps suburban per resident tax bases high. The suburbs can thus afford to maintain a much higher standard of municipal services. ${ }^{12}$ The impact of exclusionary zoning falls most heavily on racial minorities, since proportionately more blacks than whites are members of low- and moderate-income families. ${ }^{13}$

It is becoming increasingly clear that the political strength of the suburbs is sufficient to discourage the federal government from attempting to break the barriers created by exclusionary zoning.."

11. See Downs, Alternative Futures for the American Ghelto, 97 DAEDALus 1336-38 (1968); Kain \& Persky, Altematives to the Guilded Gletlo, 14 Puulic Istranast 74 (1969); Stone, Bare Cupboard, Wall St. Journal, Dec. 30, 1970, at 1, col. 6; Hamilton, Dlood is Drawn as Lindsay Lay's Off Employees, N.Y. Times, Nov. 22, 1970, \$ 4, at 5, col. 1.

12. Perhaps the most significant of these local services is culucation. Central city public schools are poorly funded and staffed in comparison with suburban schools. See, e.g., I U.S. Commission on Civil Richts, Racial Isolation in tile public Sciools 13 (1967) and U.S. Commission on Civil Rights, Demograinic, Economic, and Social. CinarACteristics of the City of St. Louis ANd St. Louis Coustr; Appendix C, Table 2 (1907). Further, one study revealed that the educational and income levels of classmates' families are more important than the teacher's education or expenditure on school facilities in contributing to the excellence of a student's education. J. ColEssax ET AL, Equalury OF Educational Opportunity 22 (1966). Such findings stress the importance of getting the children of low-income families into suburban schools where their classmates will be from "educationally motivated" families. See Downs, Alternative Futures for the Ameri. can Ghetto, 97 DaEdalus 1336-38 (1968). KERNER REPORT, supra note 9, at 399 . If the Coleman analysis is correct, then in order to give the children of the poorly edicated low and moderate-income central city families an education approsching the excellence of that received by suburban children it will be necessary to place them in schools with the suburban children.

13. The distribution of families by income indicates that in 1968 the proportion of non-white families $(44.6 \%)$, which fell into income ranges eligible for low-rent public housing (under $\$ 4,999$ ) was over twice that for white families (19.9\%). DEv'T OF CosMERCE, BUREaU of the Census, CuRrent Population Reports (Series P.60, Nos. 53 and $59,1970)$. In 1968, using the poverty index of the Social Security Administration, over $28 \%$ of non-white families in the nation were poverty stricken compared to only $8 \%$ of the white families. 1968 HUD Statistical. YeArBook, at Table 33 (based on preliminary data of Department of Commerce, Bureau of the Census). See also Natiosal Cosisissios on Urban Problems, Bullding the American Crty 45 (1968). The 1970 census figures show that in the nation as a whole black families have an average income only $61 \%$ that of white families. Rosenthal, Census Data Show Blacks Still Poor, X.Y. Times, Fcb. 12,1971 , at 1 , col. 8 and 24 , col. 6 . Only $4.5 \%$ of the suburban population is black, while blacks compose $23 \%$ of the central city population and over $11 \%$ of the national popu. lation. Rosenthal, More Blacks in Suburbs, but Ratio Stays Stable, N.Y. Times, Feb. 11, 1971 , at 1 , col. 5 and 24, col. 1. Moreover, the percentage of blacks in the suburbs is not increasing, while it is increasing rapidly in the central citics. Id. The Prestoest's SEcoNo ANnual Report on National Housing Goals, H.R. Doc. No. 292, 9lst Cong., 24 Sess. 42 (1970) stated:

[I]t is difficult, if not impossible in many communities to find sites for low- and moderate-income housing because the occupants will be poor, or will be members of a racial minority, or both. The consequence is that either no low- or moderateincome housing is built or that it is built only in the inner city, thus heightening

the tendency for racial polarization in our socicty .....

14. The Nixon administration has even been reluctant to push for federal funding of low-cost housing in those suburbs where zoning laws permit high density housing but public sentiment is against it. During the first nine months of 1970 Secretary Romney had initiated plans to place federally subsidized housing in the suburbs. His cfforts, however, have met with very limited success, apparently because of strong opposition from within the Nixon administration. See Herbers, Challenge to "White Pou'er" in the Suburbs, N.Y. Times, Nov. 15, 1970, $\$ 4$, at 5, col. 4; Herbers, Mitchell is Said to Advise 


\begin{abstract}
Although a very few states and metropolitan areas have moved to overcome exclusionary zoning, ${ }^{15}$ the poor will probably receive little relief unless the courts act.
\end{abstract}

Romney to Take New Post, Dispute on Housing Policy Reported, N.Y. Times, Nov, 22, 1970 , at 1 , col. 5 .

The following exchange occurred at a presidential news conference on December 10, 1970:

O. Mr. President, concerning Governor Romney's plan, to what extent does the Federal Government use its leverage to promote racial integration in suburban housing?

A. Only to the extent that the law requires. In two cases, as a result of acts passed by the Congress, that [sic] the Federal Government not provide aid to housing or to urban renewal where a community has a policy of discrimination and has taken no steps to remove it.

On the other hand, I can assure [sic] that it is not the policy of the Government to use the power of the Federal Government or Federal funds, in any other way, in ways not required by the law for forced integration in the suburbs. I believe that forced integration in the suburbs is not in the national interest.

6 Weekly Compilation of Presidential Documents 1650, 1653 (Dec. 14, 1970) (cmpha. sis added). See also Rosenthal, President Reaffirms Opposition to Forced Suburban Intcgration, N.Y. Times, Feb. 18, 1971, at 19, col. 4.

In his June, 1971, statement on equal housing opportunity, President Nixon cchocd his earlier position by stating that his administration "will not seck to impose cconomic integration upon an existing local jurisdiction ... Federal Policies Relative to Equal Housing Opportunity, Statement by the President, 7 WeEkLY ComplLATION OF Presidential Documents 892, 900 (June 14, 1971). However, he did indicate that his administration might work against land-use regulations which have a racially discrimi. natory impact:

[W]e will not countenance any use of economic measures as a subterfuge for racial discrimination.

When such an action is called into question we will study its effect. If the effect of the action is to exclude Americans from equal housing opportunity on the basis of their race, religion or ethnic background, we will vigorously oppose it by whatever means are most appropriate-regardless of the rationale which may have cloakcd the discriminatory act.

Id. This passage suggests that the Nixon administration might act against land-use laws which have the effect of racial discrimination in the housing field regardless of discriminatory intent. But President Nixon contradicts himself by suggesting that the federal government will act only against communities which have a racially discrimina. tory motivation for passing or enforcing their zoning laws. Id. at 904.

On the other hand, there have been two recent initiatives by the Nixon administration which show that it is taking some affirmative action toward dispersing low-income and racial minority people outward from the central city ghettos. The Justice Department has joined in a suit to compel Black Jack, Missouri, a St. Louis suburb, to accept a low-income housing project. United States v. City of Black Jack, Civil Action No. 716 372 (A) (E.D. Mo., 1971). The Department of Housing and Urban Development has proposed new site selection criteria for funding rent supplement and low-rent supplement applications. Proposed HUD Reg., 36 Fed. Reg. 19316 (1971). If these regulations arc adopted they will give HUD funding priority to sites which will act to disperse low. income and racial minorities into affluent areas of the central cities and into the sub. urbs. But see Warren Keeps Most of Its Castles Intact and Open Communities: Frozen Federal Levers, City Magazine, Jan./Feb. 1971, at 72, 77.

Racial and class discrimination are often inextricably related. Indecd, racial discrimi. nation may often be best explained as based upon class discrimination, i.e., race is often only a shorthand means of identifying certain social and cconomic classcs. Blacks may receive poor treatment in part because they are assumed to have the tratits of poor persons, even if their behavior is, in reality, the same as middle class whites. See 1 . Banfield, The Unheaventy City 63, 75-78 (1970); M. Gordon, Assimilation in AmeztCAN LIFE 46, 51-52 (1964); Bloom, Whiteman, \& Deutsch, Race and Social Class as Separate Factors Related to Social Environment 70 AM. J. Sociol. 471, 476 (1965).

15. Currently Massachusetts is the only state which requires that its towns permit a quota of land to be developed for moderate and low-cost housing. MASS. GEN. LAws 


\section{Legal Arguments Against Exclusionary Zoning}

The arguments against exclusionary zoning have been based primarily on the equal protection clause of the Fourteenth Amendment and to a lesser extent on the due process clause of the Fourteenth and Fifth Amendments. ${ }^{10}$ Recent state and lower federal court decisions indicate that some courts are willing to respond to these arguments and to restrict local zoning powers in order to accommodate the pressing social need for low- and moderate-cost housing in the suburbs.

\section{A. Due Process}

A few state courts have ruled against exclusionary zoning practices on due process grounds. Several recent Pennsylvania Supreme Court cases set forth the rule that a city must normally permit every type

ch. 408, $\$ 2023$ (1969). However, New York has given its Urban Development Corporation the power to override local zoning ordinances for certain low-cost housing projects. See New York State Urban Development Corporation Act, N.Y. Usicoxisol. LAW $\$ 625$ (McKinney 1968). See also To The Legislature: A Blueprint for Housing in New Jersey, A Special Message by William T. Cahill, Governor of New Jersey, Dec 7, 1970 (mimeo. on file with the Yale Law Journal). A metropolitan regional agreement has been reached in the Dayton, Ohio, area, in which most of the suburbs have agreed to build some low-cost housing. Herbers, Suburbs Accept Poor in Ohio Housing Plan, N.Y. Times, Dec. 21, 1970, at 1 , col. 2 and 42, col. 1. On the future prospects for state legislation to end exclusionary zoning, see Testimony of Professor David Trubck Before the United States Civil Rights Commission (June 15, 1971) (on file at the Yale Low Joumal).

16. It has also been suggested that impediments to the building of low-cost housing are a violation of the constitutional right to travel. See Note, Zoning: Closing the Economic Gap, 43 TEMPLE L.Q. 347, 353, 354 n.42 (1970); Brief for the National Urban Coalition et al. as Amicus Curiae at 46-52, James v. Valtierra, 402 U.S. 137 (1971) Ihereinafter cited as NUC Brief]. The right to travel has been based on various parts of the Constitution, including the privileges and immunities clause of Article IV, $\$ 2$, the privileges and immunities clause of the Fourteenth Amendment, the commerce clause and the due process clause of the Fifth Amendment. It has also been considered a fundamental right which flows from the general principles upon which the constitution is based. See Shapiro v. Thompson, 394 U.S. 618, 630 n.8, 631 (1968).

The right to travel announced in Shapiro encompassed not only the right to pass from state to state, but also the right to settle in whatever state a citizen might choose regardless of his wealth. A de facto barrier to the building of low-cost housing inhibits interstate movement of poor and moderate-income families just as the velfare residency requirement declared unconstitutional in Shapiro did. The cumulative effeet of the exclusionary zoning of the suburban rings around major cities is to deny many potential poor and moderate-income migrants to a state the opportunity to send their children to quality public schools and convenient access to suburban job markets. A denial of access to the suburbs is a denial of the right to personal and family advancement stemming from a change in residence which is the essence of the right to travel.

Although the right to travel argument has occasionally been presented to courts in zoning cases, no court has explicitly dealt with it in the zoning context. And, in fact, there are difficulties in extending right to travel doctrine to exclusionary zoning. First, the "fit" of the welfare legislation in Shapiro and the pauper legislation in Edwards $v$. California, 314 U.S. 160 (1941), to those poor who wished to move to a different state was much tighter than the exclusionary zoning "fit." Most people, cren poor people, can find some place to live in another state regardless of the other state's zoning laws. Second, zoning laws apply to long time residents of a state or community as well as those outside. Unlike Shapiro and Edwards, the impact of exclusionary zoning does not exclusively fall upon migrants. 
of land-use somewhere within its boundaries. ${ }^{17}$ Other state courts have decreed that cities must permit trailer parks, ${ }^{18}$ apartment buildings, ${ }^{19}$ or buildings of small floor space..$^{20}$ The underlying rationale of these decisions is that, to be a valid use of the police power, zoning must further the general welfare; and that population pressures and the exacerbation of the urban-suburban dichotomy have altered what may count as advancing the general welfare. They indicate that "general welfare" must include more than the needs or desires of the majority of the present citizens of an individual suburb and that the need for intensive land development to accommodate current metropolitan population pressures is sufficient to establish that exclusionary zoning regulations are not always consistent with the general welfare.

The possibility that this substantive due process rationale will be employed by federal courts is remote. ${ }^{21}$ But state due process zoning decisions are nonetheless significant, both for their local impact and

17. See Concord Twp. Appeal, 439 Pa. 466, 268 A.2d 765 (1970); National Land and Inv. Co. v. Easttown Township Bd. of Adjustment, 419 Pa. 504, 215 A.2d 597 (1965). For comment on this line of cases, see Note, Zoning: Closing the Economic Gap, 43 Texple L.Q. 347 (1970). "Economic due process" is still an active doctrine in state courts. See, e.g., Opinions of the Justices, 322 Mass. 755, 760, 761, 79 N.E.2d 883, 887, 888 (1948); Carpenter, Economic Due Process and the State Courts, 45 A.B.A.J. 1027 (1959); Monaghan, The Constitution and Occupational Licensing in Massachusetts, 41 B.U.L.REV. 157,160 (1961).

18. See, e.g., Lakeland Bluff, Inc. v. County of Will, 114 Ill. App. 2d 267, 252 N.E. $2 d 765$ (1969).

19. See Id.; Oakwood at Madison, Inc. v. Township of Madison, 117 N.J. Super. 11, A.2d _. (1971).

20. See, e.g., City of Phoenix v. Burke, 9 Ariz. App. 395, 452 P.2d 722 (1969) ; Cf. Renshaw v. Coldwater Housing Comm'n, 381 Mich. 590 , 165 N.W. $2 d 5$ (1969); Elizabcth Lake Estates v. Waterford Twp., 317 Mich. 359, 26 N.W. $2 d 788$ (1947).

21. The pre-Roosevelt Court was willing to rule against zoning statutes on duc process grounds. See Nectow v. City of Cambridge, 277 U.S. 183 (1928). Howcver, the Court's unwillingness to revive substantive due process in the zoning field has frequently been demonstrated. For example, appeals were dismissed in cases which upheld a threc-acre minimum lot size, Flora Realty \& Inv. Co. v. City of Ladue, 362 Mo. 1025, 246 S.W. 2d 771 (1952), appeal dismissed, 344 U.S. 802 (1952) and large floor-space minimums for homes in an area of over twenty-five square miles, Lionshead Lake, Inc. $v$. Township of Wayne, 10 N.J. 165, 89 A.2d 693 (1952), appeal dismissed, 344 U.S. 919 (1953), against due process challenges. Cf. Ferguson v. Skrupa, 372 U.S. 726, 730 (1963). Btit sec Griswold v. Connecticut, 381 U.S. 479 (1965). Similarly, most state courts follow the rule that zoning regulations are presumed to be a valid use of the police power unless shown to be clearly arbitrary and unreasonable. They have usually upheld large minimum lot size requirements against due process challenges. See, e.g., Flora Realty \& Inv. Co. v. City of Ladue, supra, (three acres); Napa Valley United Farmers v. County Bd. of Supcrvisors, No. 24, 961 (Napa County Calif. Super. Ct. 1970) (twenty acres in order to preserve agriculture); Simon v. Town of Needham, 311 Mass. 560, 42 N.E.2d 516 (1942) (one acre). See generally Babcock \& Bosselman, Suburban Zoning and the Apartment Boom, 111 U. PA. L. REv. 1040 (1963); Cutler, Legal and Illegal Methods for Controlling Com. munity Growth on the Urban Fringe, 1961 WIs. L. REv. 370, 383.84. Large minimum floor area requirements are also generally upheld against due process challenges. Sce Lionshead Lake, Inc. v. Township of Wayne, supra; Note, Snob Zoning-A Look at the Economic and Social Impact of Low Density Zoning, 15 SYRACUSE L. REv. 507, 511.12 (1964). Even complete prohibition of apartment building is sometimes upheld. In Valley View Village v. Proffett, 221 F.2d 412 (6th Cir. 1955), zoning of an entire village for single family housing was held not invalid per se. 
as part of an evolving judicial recognition that it is necessary for communities to consider metropolitan land-use needs when applying local zoning laws.

\section{B. Equal Protection}

The central legal argument of those who oppose exclusionary zoning has been that it violates the equal protection clause.? They argue that exclusionary zoning statutes must be measured by a compelling state interest ${ }^{23}$ rather than a rationality standard because such statutes discriminate against two classes entitled to special judicial protection, racial minorities and the poor, and deny citizens their "fundamental interest" in housing. Opponents of exclusionary zoning contend, in this connection, that the compelling state interest test applies when the effect of a zoning statute is to discriminate against a racial minority or the poor, although the legislators who passed the zoning law may not have had a discriminatory motive or purpose. It has also been suggested that the presence of certain combinations of classifications or interests, no single one of which is "suspect" or "fundamental," may operate jointly to impose a more stringent standard of judicial review. These various contentions may usefully be accorded separate treatment.

\section{Race as a Suspect Classification}

When a zoning regulation explicitly states that a racial minority is a "nuisance" to be excluded from an area, it clearly violates the equal protection rights of the zoned-out minority. ${ }^{24}$ But it is currently undecided whether the statistically demonstrable racial impact of exclusionary zoning is sufficient to impose the compelling state interest test without a showing of racially discriminatory purpose or motive

22. See, e.g., Sager, Tight Little Islands: Exclusionary Zoning;, Equal Protection, and the Indigent, 21 STAN. L. Rev. 767 (1969); Note, Exclusionary Zoning and Equal Pro. tection, 84 HARv. L. Rev. 1645 (1971); Note, The Constitutionality of Local Zoning, 79 Yale L.J. 896 (1970). For case support, see, e.g., Dailey v. City of Lawton, 425 F.2d 1037 (10th Cir. 1970): SASSO v. Union City, 424 F.2d 291 (9th Cir. 1970); Kennedy Park Homes Ass'n v. City of Lackawanna, 318 F. Supp. 669 (W.D.N.X. 1970), aff'd, 436 F.2d 108 (2d Cir. 1970), cert. denied, 401 U.S. 1010 (1971). See also Michelman, The Advent of a Right to Housing: A Current Appraisal, 5 HARv. CIv. RICITS-Civ. LID. I. REv. 207 (1970); Coons, Clune, and Sugarman, Educational Opporlunity: A Worhable Constitutional Test for State Financial Structures, 57 CALIF. L. REv. 305 (1969) (application of equal protection doctrine to education).

23. In only the World War II Japanese internment cases has the Court erer held that governmental action furthered a compelling state interest. See, e.g., Korematsu v. United States, 323 U.S. 214 (1944).

24. Buchanan v. Warley, 245 U.S. 60 (1917). 
on the part of those who passed the zoning statute or those who administer it. In zoning litigation it is often impossible, and always very difficult, to prove that zoning boards had a racially discriminatory motive or purpose. ${ }^{25}$ Therefore, if racial discrimination arguments are to succeed in a zoning context, they will depend on a determination that a showing of racially discriminatory effect of zoning laws is stfficient to trigger the compelling state interest standard of judicial review.

There have been a few lower court decisions which hold or suggest that a showing of racially discriminatory effect is sufficient to require stringent equal protection review. ${ }^{20}$ In Southern Alameda Spanish Speaking Organization [SASSO] v. Union City, the Court of Appeals for the Ninth Circuit declared that the environmental control purpose claimed by the city in excluding a housing project which would have been inhabited mainly by Mexican-Americans was "perfectly legitimate."27 It refused to examine the motives of the Union City residents who voted by referendum not to grant the plaintiff organization a zoning variance for a low-cost housing project, on the grounds that it is practically impossible to determine motivation. The court looked instead to the impact of the zoning referendum as the basis

25. The dictionary defines "motive" as "something that prompts a person to act in a certain way or that determines volition; incentive." THE RANDOM HOUSE DicrionAkY OF THE ENGLish LANGUAGe (unabridged ed. 1967). This Note uses "purpose" to mean the effect which the lawmakers or administrators expect to accomplish by the making or administration of the law. It should be observed, however, that courts generally use "motive" and "purpose" interchangeably. See, e.g., United States v. O'Brien, 391 U.S. 367, 383 (1968) ; Ely, Legislative and Administrative Motivation in Constitulional Law, 79 YALE L.J. 1205, $1216(1970)$. For a discussion of judicial treatment of legislative and administrative purpose and motive, see Ely, supra. Zoning Boards can freclucntly dem. onstrate that their main criteria for zoning regulations were environmental.

26. Norwalk CORE v. Norwalk Redevelopment Agency, 395 F.2d 920 (2d Cir. 1968), involved rehousing those displaced by urban renewal. The court recognized that statutory provisions providing for rehousing were on their face neutral between races. The ad. ministrative agency charged with rehousing the displaced had also spent approximately equal time trying to place black and white persons. However, because of conditions in the housing market which made it much more difficult to find new housing for blacks than for whites, the effect of the rehousing legislation and its administration was to find housing for a much higher percentage of displaced whites than of displaced blacks, The effect was unequal and, therefore, the court concluded, the equal protection rights of the blacks were violated. Norwalk $C O R E$ relied heavily on Hobson v. Hanscn, 269 F. Supp. 401 (D.D.C. 1967), aff'd sub. nom. Smuck v. Hobson, 395 F.2d 920 (D.C. Cir. 1968), in which the court found that an unconstitutional de facto discriminatory effect had resulted from the neighborhood schools and tracking policies followed by the Washington, D.C. Board of Education:

The complaint that analytically no violation of equal protection vests unless the inequalities stem from a deliberately discriminatory plan . . . is simply false. What. ever the law was once, it is a testament to our maturing concept of equality that, with the help of Supreme Court decisions in the last decade, we now firmly recognize that the arbitrary quality of thoughtlessness can be as disastrous and unfair to private rights and the public interest as the perversity of a willful scheme.

269 F. Supp. at 497.

27. 424 F.2d 291, 295 (1970). 
for its decision to remand the case to the district court for factual findings and remedy. Its concern was that the effect of the zoning ordinance may have been to "deny housing and an integrated environment to low-income residents." 28

The Supreme Court has not yet resolved this issue. The Court has declined to reverse a recent lower court decision which held that zoning laws that have a racially discriminatory effect violate the equal protection clause. Certiorari was denied in Kennedy Park Homes $v$. Lackawanna, ${ }^{29}$ where the Second Circuit had ordered the city to remove its freeze on subdivision development and issue a variance to allow the building of a low-cost housing project to be inhabited principally by blacks. But the Court has not articulated criteria for reviewing state action which has a racially discriminatory impact. ${ }^{30}$

\section{Classification by Wealth and the Interest in Housing}

Exclusionary zoning clearly strikes most heavily against the poor. At least one exclusionary zoning case, SASSO, appears to treat wealth as a suspect classification. ${ }^{31}$ It is also clear that the Supreme Court is willing to declare suspect some types of classifications which disadvantage the poor. ${ }^{32}$ Proponents of this trend argue that the poor, like

28. Id. at 295.96 .

29. 436 F.2d 108 (2d Cir. 1970), cert. denied, 401 U.S. 1010 (1971). The Second Circuit held that racially discriminatory effect is by itself sufficient to require a "suspect classification" test:

Even were we to accept the City's allegation that any discrimination here resulted from thoughtlessness rather than a purposeful scheme, the City may not escape responsibility for placing its black citizens under a severe disadsantage which it cannot justify.

Id. at 114. In an alternate holding the court upheld the district court's finding that the city's refusal to allow the project to go forvard was based on "racial motivation," and that effect is an important element of proof for showing motive. Id. at 112.

30. See pp. $73-76$ infra.

31. 424 F.2d 291 (9th Cir. 1970). The court of appeals opinion in SASSO repeatedly coupled its references to "low-income family" and racial minorities. But the court does not make clear its thoughts on classification by wealth. It does not cite any of the voting rights or criminal appeal cases (cited in note $32 \mathrm{in} / \mathrm{ra}$ ) as precedents, nor does it sufficiently divorce its language about low-income and racial minorities to assure the reader that it considers the former to be a suspect classification. The court of appeals returned the case to the district court for a finding of facts and imposition of remedies. Judge Sweigert, in his district court opinion, S.ASSO v. Union City, Civil No. 51590 (N.D. Cal., July 30, 1970), appears to interpret the circuit court's holding as a declaration that classification by wealth is suspect. He does not religiously combine the race and wealth classifications as did the circuit court, but instead often deals with low-income citizens alone as the class discriminated against. Id. at 20, 21. In Serrano v. Priest, 5 Cal. 3d 584, 487 P.2d 1241, 96 Cal. Rptr. 601 (1971), the Supreme Court of Californin held classification by wealth to be suspect.

32. See, e.g., Sager, supra note 22, at 774-80; Note, Exclusionary Zoning and Equal Protection, 84 HARv. L. REv. 1645, 1657.62 (1971). Those who argue that the Court is establishing wealth as a suspect classification usually point to a group of voting rights and judicial rights cases. In Harper v. Virginia Bd. of Elections, 383 U.S. 603 (1965), the Court declared that indigents could not be deprived of the right to vote because 
racial minorities, are in need of special protection if they are not to be exploited by the rest of society and deprived of basic political and judicial rights as well as educational and employment opportunities..$^{\text {Ju }}$ Indeed, classification by wealth, though usually de facto, seems to share with classification by race the characteristic of being "invidious." Both types of classification may be used by a majority of society to oppress a minority or to stigmatize a group in society as inherently inferior, and both classifications are frequently unnecessary to the pursuit of any valid governmental objective. ${ }^{34}$ Judicial reluctance, thus far, to accept this argument completely may derive from the fact that while race is a permanent attribute, poverty is thought to be a transitory state of being from which one or one's children can pass with hard work. The Court's difficulty in deciding which wealth classifications are suspect may thus be attributable to the paradoxical position society takes with respect to wealth. Our society at once embraces both the principle that every man is entitled to equal opportunity for social and economic advancement and the principle that distinctions based on wealth are normal and even desirable as incentives. ${ }^{35}$ The Court cannot avoid wrestling with this paradox in its attempt to define which wealth classifications should prompt stringent constitutional review.

Another closely related approach to protecting the poor focuses on the means necessary for economic and social advancement. Although the Court has not yet held housing to be a fundamental interest, ${ }^{30}$ it has declared that certain rights essential for effective participation in our judicial and political systems must be made available to all citizens regardless of their ability to pay. ${ }^{37}$ At least one of these fundamental

of inability to pay a poll tax. In Douglas v. California, 372 U.S. 353 (1963), it held that indigents had to be provided with legal counsel to help prepare criminal appeals. Sece also Tate v. Short, 401 U.S. 395 (1971); Williams v. Illinois, 399 U.S. 235 (1970); Griffin v. Illinois, 351 U.S. 12 (1956). See also McDonald v. Board of Election Comm'rs, 391 U.S. 802, 807 (1969) (dictum):

[A] careful examination on our part is especially warranted where lines are drawn on the basis of wealth or race, ... two factors which would independently render a classification highly suspect and thereby demand a more exacting judicial scrutiny.

33. See pp. 62-64 supra.

34. See generally Michelman, The Supreme Court, 1968 Term-Foreword: On Pro. tecting the Poor Through the Fourteenth Amendment, 83 HARv. L. REv. 7, 20, 21 (1969).

35. For a discussion of this paradox, see J. GARDNER, EXCELlENCE 21.29 (1961).

36. However, the Court has declared housing to be a matter of special judicial con. cern. See Jones v. Alfred Mayer Co., 392 U.S. 409, 441.44 (1968); Reitman v. Mulkey, 387 U.S. 369, 385 (1967) (Douglas, J., concurring); Shelley v. Kraemer, 334 U.S. 1, 10 (1948).

37. See, e.g., Shapiro v. Thompson, 394 U.S. 618, 628.31 (1969); Harper v. Virginia Bd. of Elections, 383 U.S. 663, 666 (1966); Douglas v. California, 372 U.S. 353 , 355 (1963); Griffin v. Illinois, 351 U.S. 12, 17-19 (1956). 
interests - the right to vote ${ }^{38}$ - shares with access to suburban housing the characteristic of being an important means of social and economic mobility. Lower courts have been willing to hold that housing and education are fundamental interests precisely because they afford access to a decent life. ${ }^{39}$ The fundamental interest approach may be the most sensible way to provide every citizen with a minimum level of those things essential to upward social and economic mobility. Concentration on the means of social and economic advancement themselves, Professor Michelman has argued, would direct the Court's attention toward the basic ethical problem of defining a guaranteed minimum standard of living, and would free it from the very difficult task of defining what types of wealth classifications are suspect. ${ }^{\text {i0 }}$

\section{Sliding Scale Argument}

Under the "sliding scale" approach, various classifications and interests are visualized as being on a gradient, with the standard of review becoming more demanding as the nature of the classifications or the value of the interests approaches the "suspect" or "fundamental" levels."1

38. See Harper v. Virginia Bd. of Elections, 383 US. 663 (1960).

39. The court of appeals opinion in SASSO can be interpreted as regarding housing as a fundamental interest:

Given the recognized importance of equal opportunities in housing, it may well be, as matter of law, that it is the responsibility of a city and its planning officials to see that the city's plan as initiated or as it develops accommodates the needs of its low-income families....

424 F.2d at 295-96. Serrano v. Priest, 5 Cal.3d 584, 487 P.2d 1241, 96 Cal. Rptr. 601 (1971), held that education is a fundamental interest. A recent Mlinnesota Federal Distriet Court opinion follows Serrano in declaring education to be a fundamental interest and wealth to be a suspect classification. Van Dusartz v. Hatfield, 40 U.S.L.W. 2228 (D. MIinn. Oct. 26, 1971).

40. See Michelman, The Advent of a Right to Housing: A Current Appraisal, 5 Harv. Civ. Rights-Civ. Lib. L. Rev. 207 (1970); Michelman, The Supreme Court, 1965 Term-Foreword: On Protecting the Poor Through the Fourteenth Amendment, 83 HARV. L. REV. 7 (1969).

41. See Cox, The Supreme Court, 1965 Term-Foreword: Constitutional Adjudication and the Promotion of Human Rights, 80 HARv. L. REv. 91, 95 (1960); Comment, De. velopments in the Law-Equal Protection, 82 Harv. L. REv. 1065, 1120 (1969).

In Williams v. Rhodes, 393 U.S. 23, 30 (1968), the Supreme Court seemed to propose a sliding scale approach. The Court held that

[i]n determining whether or not a state law violates the Equal Protection Clause, we must consider the facts and circumstances behind the law, the interests which the State claims to be protecting, and the interests of those who are disadvantaged by the classification.

393 U.S. 23 at 30 (1968). Justice Marshall apparently relied upon such an approach in his Dandridge dissent:

In my view equal protection analysis of this case is not appreciably adranced by the a priori definition of a "right," fundamental or otherwise. Rather, concentration must be placed upon the character of the classification in question, the relative importance to individuals in the class discriminated against of the governmental 
The suspect and fundamental qualities of the classifications created and the interests regulated by a specific state action are evaluated and weighed together in determining the standard of judicial review to be applied. This approach frees the court from the artificial strictures of an all-or-nothing analysis vis-a-vis particular classifications and interests and allows it to impose stringent judicial scrutiny on certain classifications in combination with some interests but not others. It would permit courts to strike down that state action affecting lowincome families which it regards as particularly pernicious while allowing other wealth classifications to stand. SASSO can be viewed as suggesting that classification by wealth, though not necessarily suspect by itself, and an interest in housing, though not necessarily fundamental by itself, when combined call for a higher standard of judicial scrutiny than would either independently. ${ }^{42}$

\section{The Impact of Valtierra and Dandridge on Equal Protection Doctrine}

Despite cries of despair to the contrary,43 Dandridge and Valtierra do not signal an end to the relevance of equal protection doctrine in assessing the constitutionality of exclusionary zoning laws. In fact, the arguments outlined above are still available, for the holdings in Valtierra and Dandridge are not dispositive of the root issues in exclusionary zoning cases. Analysis of those two cases will be placed in the same framework as the foregoing general analysis of the equal protection challenge to exclusionary zoning. ${ }^{44}$

benefits that they do not receive, and the asserted state interests in support of the classification.

397 U.S. at $520-21$ (1970).

It is evident that certain types of classifications tend to be more invidious than others. For example, in recent years labor unions have done quite well in preventing, through the political process, governmental action which discriminates against unions or against their members, while racial minorities have not been successful in preventing govern. mental action which disadvantages them. The likelihood that state action is dirccted at hindering the ability of various groups to participate in the burdens and benefits of society on an equal basis with other citizens varies greatly among classifications. Similarly, interests may be more or less important or fundamental. For example, the right to volc is an essential means of protecting and advancing a group's welfare. The interest in equal access to state owned recreation facilities which charge admission fees is clearly less crucial for social and economic advancement. Housing would seem to warrant a relatively high rating on this scale.

42. See 424 F.2d at 295.96. In Serrano v. Priest, 5 Cal.3d 584, 487 P.2d 1241, 96 Cal. Rptr. 601 (1971), the California Supreme Court appears to have employed the sliding scale approach when it found the combination of classification by wealth and interest
in education to require the compelling state interest test.

43. See note 6 supra.

44. See Section IIB supra. 


\section{A. Race as a Suspect Classification}

At first glance Valtierra appears to reject the proposition that a land-use law which has a racially discriminatory effect may violate the equal protection clause. Justice Black, writing for the five-man majority, stressed that the referendum procedure utilized in Vallierra was neither racially discriminatory on its face nor clearly discriminatory in purpose. It applied to all publicly financed low-cost housing, "not only [to] ... projects which will be occupied by a racial minority." 46 Nor, Justice Black emphasized, did "the record . . . support any claim that a law seemingly neutral [with respect to race] on its face is in fact aimed at a racial minority." 40 Valtierra might, therefore, be interpreted as advancing the rule that only legislation which is racially discriminatory on its face or is racially motivated triggers the stringent scrutiny applied to suspect classifications.

The Court's refusal to rule on the basis of racially discriminatory impact may, however, have been prompted by a desire to avoid announcing a standard which would have extremely broad implications. Indeed, the majority opinion emphasized that the Court will not attempt to make all government decisions affect all individuals equally. ${ }^{47}$ To accept the discriminatory effect argument without qualification, the Court implied, would be to set a precedent that stringent judicial scrutiny is required whenever the impact of a statute falls disproportionately upon members of a racial minority. ${ }^{48}$ Such a sweeping standard would plainly be difficult to contain. It would require a compelling state interest to justify state action, including remedial $^{49}$ and other programs in a wide range of areas, without any consideration of the invidiousness of the particular legislation under review. Similarly, the Court applied the "rational basis" standard of review in Dandridge. There the effect of the law setting a maximum limit for welfare payments fell more heavily on blacks than whites, because a greater percentage of blacks than whites are on welfare and because blacks on the average have larger families. ${ }^{50}$ The Court, however, chose to treat the Maryland welfare law as a simple economic regulation and refused to impose the compelling state interest test.

\footnotetext{
45.402 U.S. at 141 .

46. Id.

47. Id. at 142.

48. Briefs submitted to the Supreme Court in Valtierra demonstrated that some of the areas involved contained a disproportionate number of non-white peoples. NUC Brief, supra note 16, at 35, 55; Brief of Appellees Anita Valtierra et al., James v. Valtierra. 402 U.S. 137 (1971). But see p. 75 and note 50 infra.

49. See pp. 77-80 infra.

50. See Council of Economic Advisers, EcoNomic Report of the Presibest 40 (1971).
} 
But it would be incorrect to interpret Valtierra and Dandridge as holding that racially discriminatory impact alone is never sufficient to require application of the compelling state interest standard. These cases must be read in light of prior decisions which suggest that the Court is prepared to invalidate laws which exclusively or almost exclusively harm members of a racial minority. In Reitman \%. Mulkey ${ }^{u 1}$ the Court ruled that an amendment to the California Constitution prohibiting open housing legislation violated the equal protection clause because it encouraged private racial discrimination, despite the fact that the amendment was not restricted to laws forbidding racial discrimination but barred all laws preventing the seller from disposing of his property to whomever and for whatever reasons he desired. Hunter $v$. Erickson ${ }^{52}$ invalidated on equal protection grounds an amendment to a city charter prohibiting the city council from implementing any ordinance regulating racial, religious, or ancestral discrimination in housing without the approval of a majority of the city's voters. Like the constitutional amendment in Reitman, the referendum procedure in Hunter applied on its face to discrimination on bases not limited to race. But as Justice White, who also wrote the Reitman opinion and was part of the Valtierra majority, observed for the Court:

[A]lthough the law on its face treats Negro and white, Jew and gentile in an identical manner, the reality is that the law's impact falls on the minority. The majority needs no protection against discrimination and if it did, a referendum might be bothersome but no more than that. ${ }^{53}$

Both the Reitman and Hunter Courts reacted to impediments to open housing legislation which, given the racial animosities of contemporary America, would have had inevitably detrimental effects on the ability of racial minorities to obtain housing. These decisions suggest that Valtierra must be carefully distinguished from cases in which (1) the fit of the regulation to racial minorities is tight, i.e., where those affected by the regulation, as in Reitman and Hunter, are all or almost all members of a racial minority, and (2) the harm to

51. 387 U.S. 369 (1967).

52. 393 U.S. 385 (1969).

53. Id. at 391. In a separate line of cases, the Supreme Court has stated that although multi-member voting districts are not per se unconstitutional, they violate the equial protection clause in a particular case if it can be shown that they operate to "minimize" or "cancel out" the voting strength of a racial minority. See Burns v. Richardson, 384 U.S. 73, 88 (1966); Fortson v. Dorsey, 379 U.S. 433, 439 (1965). Just last term the Coutt reaffirmed its position that multi-member districts may have an unconstitutional dis. criminatory impact on racial minorities in Whitcomb v. Chavis, 403 U.S. 124 (1971), though it found the proof offered in that case to be inadequate. 
those affected can be clearly demonstrated. Such a distinction is not only suggested by recent precedents, but also strongly supported by the fact that de facto classifications possessing these two features have the same characteristics of invidiousness which render de jure racial classifications suspect. ${ }^{5 \neq}$ The act of placing a racial minority in an exclusive or nearly exclusive class detrimental to its interests can have a severe stigmatizing effect even in the absence of explicit de jure language. In addition, there is a great danger of majoritarian oppression when those harmed are exclusively members of a racial minority. Legislatures and voters may cast burdens upon racial minorities which they would not be prepared to force other groups to bear. Finally, it is doubtful that classifications which harm only racial minorities are necessary to the pursuit of legitimate legislative goals. They will frequently be grossly over- or under-inclusive.

It is clear that the fact situations in Dandridge and Vallierra satisfied neither the "fit" nor "harm" criteria. This is obviously true of Dandridge, since a substantial number of welfare recipients with large families were white. ${ }^{55}$ The Valtierra Court also may have felt that the "fit" of Article XXXIV was too loose to warrant the imposition of the compelling state interest test. For example, the brief of appellant Shaffer in Shaffer $v$. Valtierra, the companion case to James $v$. Valtierra, pointed out that "only $1.4 \%$ of the households [in one of the areas to be served by the public housing project in question] of an income of $\$ 3,000$ or less are Negroes." ${ }^{\circ 6}$ In addition, Valtierra involved circumstances which are only sometimes disadvantageous to racial minorities. The defeat of a single housing proposal in a referendum would not necessarily be harmful. For it is open to doubt that every housing project proposed on behalf of racial minorities actually benefits them. Distance from jobs and schools, effect on traffic patterns, availability of more desirable alternatives, and a host of other considerations might weigh against the desirability of any particular project. Valtierra might have been decided differently if the Court had been confronted with a record establishing that the referendum procedure operated to deprive blacks or other racial minorities of an adequate supply of low-cost housing.

54. See p. 70 supra.

55. Cf. COUNCIL OF ECONOMIC Advisers, ECONOMIC Rerort OF TUE PRESIDENT 10 (1971).

56. Brief of Appellant Shaffer at 30, Shaffer v. Valtierra, 402 U.S. 137 (1971). This fact must have greatly diluted the impact of the appellees statement:

[In the nation as a whole] racial minorities are over-represented in the low-income group and in the occupation of overcrowded housing.

Brief of Appellees Anita Valtierra et al., Shaffer v. Valtierra, 402 U.S. 137 (1971). 
Although it is obvious that exclusionary zoning does not always principally harm racial minorities, doubtless there are instances in which restrictive zoning policies meet the "fit" and "harm" criteria. For example, Kennedy Park Homes v. Lackawanna, ${ }^{57}$ in which the court of appeals suggested that racially discriminatory effect alonc is sufficient to require the compelling state interest test, differed from Valtierra and Dandridge in these two critical respects. The district court in Lackawanna found that those excluded by the city's zoning practices were almost exclusively blacks and that they were clearly harmed by being deprived of access to adequate low-cost housing: ${ }^{\text {s }}$ Unfortunately, there is no magic percentage at which the fit auto. matically becomes tight. Nevertheless these two distinguishing characteristics would, in general, permit courts to protect racial minorities from the consequences of exclusionary zoning in those cases wherc the community's action is most invidious. ${ }^{50}$

\section{B. Wealth as a Suspect Classification and Housing as a Fundamental Interest: A Benefit-Burden Distinction}

Dandridge and Valtierra seem firmly to reject the broad proposition that the government has a general obligation to cure existing economic inequalities or provide an adequate supply of low-income housing. But they do not foreclose the possibility that under some circumstances classification by wealth is suspect and the interest in housing fundamental. Rather than representing an abrupt departure from the "new equal protection," Dandridge and Valtierra can be reconciled with previous decisions fully cognizant of the stringent judicial scrutiny required to protect basic values.

Although the Supreme Court has repeatedly insisted that suspect classifications and infringements of fundamental interests are to be

57. 318 F. Supp. 669 (W.D.N.Y. 1970), aff'd, 436 F.2d 108 (2d Cir. 1970), cert. denied, 401 U.S. 1010 (1971).

58. In SASSO, too, the fit was close and there was clearly demonstrated harm. Scc SASSO v. Union City, Civil No. 51590 (N.D. Cal., July 30, 1970).

59. It would seem that the arguments made in this section are also relevant to wealth and housing and that those made in the next section are also relevant to racc. Surcly classifications which exclusively disadvantage the poor possess certain invidiouts characteristics. See p. 70 supra. Nevertheless wealth classifications are at least slightly less invidious than racial classifications and, probably unlike the latter, seem to lose much of their invidious quality when created by a remedial program, such as publicly financed housing. Cf. O'Neil, Preferential Admissions: Equalizing the Access of Minority Groups to Higher Education, 80 YALE L.J. 699, 709-11 (1971) (regarding beneficent racial classifications). The same applies to housing as a fundamental interest. Clearly a demonstration that the referendum procedure in Vallierra operated to deprive citizens of decent housing would have been necessary to establish that an interest in housing had been infringed. This section will argue, however, that such a showing may not have been sufficient, given the fact that the referendum applied only to publicly financed housing. 
presumed unconstitutional, ${ }^{60}$ it has displayed much greater flexibility in defining when classifications are suspect and interests fundamental. Past decisions reveal that despite its explicit statements concerning the fundamental nature of the franchise and the suspect nature of wealth classifications, the Court has refused to declare that all governmental action making it significantly more difficult for one group to exercise the franchise than another or primarily affecting the poor automatically triggers stringent judicial scrutiny. In particular, the Court has generally refused to apply the compelling state interest standard to distinctions of a suspect character or which restrict fundamental interests when the challenged legislation is of a remedial nature. Where the government has voluntarily shouldered the burden of extending fundamental interests and reducing discrimination against a specially protected class to a degree beyond that which the Constitution demands, ${ }^{01}$ the Court has been unwilling to demand more than rationality. This theme is best illustrated, ironically enough, by two cases often cited as examples of the expansive scope of the equal protection theory developed by the Warren Court, ${ }^{02}$ Kalzenbach v. Morgan ${ }^{63}$ and McDonald v. Board of Election Commissioners. ${ }^{\circ 4}$

Morgan involved a challenge to the constitutionality of Section $4(\mathrm{c})$ of the Voting Rights Act of $1965^{\circ 5}$ prohibiting the application of English language literacy tests to, inter alia, those educated in Spanish language schools in Puerto Rico. Among the arguments considered by the Court was the contention that the prohibition of the enforcement of English literacy requirements only for those educated in foreign language schools within the jurisdiction of the United States and not for those educated in foreign language schools beyond the territorial limits of the United States violated the Fifth Amendment.00 It would seem that a compelling state interest standard was in order. The remaining literacy tests clearly placed a significant burden on the right to vote of those educated in foreign language schools outside

60. See pp. 67-71 supra.

61. As a theoretical matter it does not follow from the fact that an interest in a good is fundamental that the government is obligated to provide it. The steady crosion of the state action requirement in such areas as racial discrimination, voting rights, and judicial rights, however, renders this distinction of little practical significance.

62. See Note, Exclusionary Zoning and Equal Protection, 84 HARv. L. REv. 1645, 1653 n. 64 (1971).

63. 384 U.S. 641 (1966).

64. 394 U.S. 802 (1969). See also Schilb v. Kuebel, 40 U.S.L.W. 4107 (U.S. Dec. 20, 1971).

65. 42 U.S.C. \& $1973 \mathrm{~b}(\mathrm{c})(1970)$.

66. See 384 U.S. at 656 . The Fifth Amendment incorporates the Fourteenth Amendment's notion of equal protection. See Shapiro v. Thompson, 394 US. 618, G1I-42 (1969); Bolling v. Sharpe, 347 U.S. 497 (1954). 
the United States. In addition, since the exemption from English language literacy tests almost exclusively affected those of Puerto Rican origin, ${ }^{67}$ it appears that the classification was drawn along racial lines. ${ }^{68}$ The majority, however, disagreed. "Section 4(e)," Justice Brennan wrote, "does not restrict or deny the franchise but in effect extends the franchise to persons who otherwise would be denied it by state law." ${ }_{00}$ Consequently,

the principle that calls for the closest scrutiny of distinctions in laws denying fundamental rights $\ldots$ is inapplicable; for the distinction challenged by appellees is presented only as a limitation on a reform measure aimed at eliminating an existing barrier to the exercise of the franchise. ${ }^{70}$

The premise implicit in the Court's reasoning was that Lassiter $v$. Northampton Election Board, ${ }^{71}$ which upheld the constitutionality of literacy tests against an equal protection attack, was still good law; that is, by abolishing English language literacy tests for some the government was operating beyond the scope of constitutional compulsion. ${ }^{7 "}$

A similar problem was resolved in a similar manner a few years later in McDonald v. Board of Election Commissioners, which dealt with a challenge by county jail inmates awaiting trial to an Illinois absentee voting statute that failed to include them among those entitled to vote in absentia. The appellants argued that the distinction which the statute made between unsentenced inmates within their resident counties and other absentees could not survive the stringent judicial scrutiny appropriate in voting rights cases. Chief Justice Warren, writing for the Court, readily accepted the proposition that legislation which curtails the right to vote or draws lines on the basis of race or wealth must be closely scrutinized. ${ }^{73}$ Nevertheless, the Court concluded that for two reasons it was "not necessary" to examine closely the Illinois absentee provisions: they were not drawn on the

67. See 384 U.S. at 645 n. 3 .

68. The Court might have been more disturbed by the invidious qualities of remedial legislation which, rather than aiding one sub-class of Spanish speaking people morc than others, benefited English speaking voters more than Spanish speaking voters. St'c note 77 infra.

69. 384 U.S. at 657 .

70. Id.

7I. 360 U.S. 45 (1959).

72. Interestingly and consistently, Justice Douglas, who had concluded in Catrdona v. Power, 384 U.S. 672 (1966), that English language literacy tests were unconstitutionil as applied to persons literate in Spanish, refused to join this portion of the Court's opinion. 384 U.S. at 658 .

73. See note 32 supra. 
basis of wealth or race, and it was the right to receive absentee ballots rather than the right to vote that was at stake. At first glance the Court appeared to be denying in one breath what it had affirmed in the previous one. The strong correlation between those lacking funds and those failing to meet bail clearly cstablished that Illinois' failure to extend the absentee ballot to pretrial detainees fell principally upon the poor, and it is plainly incorrect to argue that the failure to grant the absentee ballot to these prisoners did not curtail their right to vote if the term "right" also includes ease of exercise. ${ }^{74}$ Furthermore, the burden placed upon the right to vote of those who could not afford bail was far from insubstantial. Although the Court never clearly articulated why the compelling state interest standard was inappropriate, its opinion emphasized various factors which might explain its holding. The Illinois statute, the Court noted, was essentially "remedial."'s Rather than placing obstacles in the way of roting, Illinois had chosen to expand the right. The Court was not prepared to rule that states have a duty to provide absentee ballots for those, rich or poor, unable to appear at the polls, and since Illinois had enacted reforms beyond the area of constitutional compulsion, the exacting scrutiny ordinarily applied to legislation creating suspect classifications or infringing fundamental interests was considered to be inappropriate. ${ }^{76}$

McDonald and Morgan seem to stand for the proposition that there are certain limits to the government's constitutional obligation to further fundamental interests and relieve the plight of racial minorities and the poor, and that when remedial action is undertaken outside the area of constitutional compulsion the stringent judicial scrutiny normally triggered by the presence of fundamental interests and suspect classifications is no longer appropriate. Although there is obviously room for disagreement concerning the precise scope of the government's

74. The Court observed that there was no showing that Illinois might not find other means to permit appellants to vote such as setting up polling booths in the jail. 394 U.S. at $808 \mathrm{n}$. 6. It is apparent from the opinion as a whole, however, that the Court regarded this rather speculative possibility as being unnecessary for its conclusion. Indeed, if the court had felt otherwise, it would have been improper for it to proceed to an adjudi. cation of the constitutional issue on the unlikely basis that such a situation prevailed rather than remanding the case for a determination of this factual issuc. Cf. Street $v$. New York, 394 U.S. 576, 594 (1969).

75. 394 U.S. at 811 .

76. The Court described Illinois' absentee ballot voting provisions as "a consistent and laudable state policy of adding, over a 50 -year period, groups to the absentec coverage as their existence comes to the attention of the legislature. That Illinois has not gone still farther, as perhaps it might, should not render void its remedial legislation, which need not, as we have stated before, 'strikc at all evils at all times." 39. U.S. at 811 (citations omitted). 
obligations, a distinction between laws falling short of constitutional standards and those going beyond the Constitution's commands appears to be plausible. As a practical matter, the application of a compelling state interest standard to statutes designed to assist and enhance the very groups and interests that the standard was designed to protect might do more harm than good by discouraging such remedial legislation. More importantly, however, classifications created by remedial programs are probably less invidious than they would otherwise be. ${ }^{77}$

The above analysis serves to distinguish Dandridge and Valtierra from the problem of exclusionary zoning. The Dandridge Court may well have reasoned that rather than disproportionately disadvantaging the poor through governmental action, the Maryland statute merely refused to extend assistance on an equal basis to a sub-class of the poor, viz. those with large families. ${ }^{8}$ Implicit in such an approach is the assumption that welfare, at least above a very minimal level, is not constitutionally required. Valtierra also sustained the constitutionality of a provision which at first glance appears to burden the poor henvily and, in addition, impair seriously efforts to increase the supply of low-income housing. Nevertheless Valtierra, like Dandridge, dealt with a legislative scheme of a remedial nature which arguably went beyond the government's constitutional obligations. It is important to observe that Valtierra only involved a barrier to the building of publicly financed housing. Those Justices who upheld Article XXXIV might have reasoned that since government does not have a constitutional obligation to supply the poor with adequate housing, the citizens of a community who bear the costs of subsidized housing should be able to decide whether they wish to spend their tax money in such a way. ${ }^{70}$

77. Thus this approach does not revive the right-privilege distinction. The latter has been justly criticized because due process serves an equally important function regardless of how the courts label the good at stake. When governmental action has a remedial thrust of the type discussed above, however, the very factor which persuaded the courts to apply the compelling state interest test in the first place, i.e., invidiousness, is di. minished. See p. 70 supra. Of course, courts should demand a conclusive demonstration that a fundamental right is being extended or the plight of a special judicially protected group is being alleviated. Equally important is judicial insistence upon a close corrclation between the manner in which a right or group is affected by the legislation and the manner in which the right or group is ostensibly being aided. Otherwise a community might contend that its exclusionary zoning statutes should escape stringent judicial scrutiny because it had voluntarily agreed to extend sewer service to all residential housing. The compelling state interest standard should probably be applicd to remedial legislation enhancing fundamental rights and the position of judicially protected groups unless it can be shown that all such rights and groups affected are benefited in a manner identical to the subject matter of the classification made by the statute. Furthermorc, stringent scrutiny should also be applied to all such remedial legislation which excludes racial minorities or the poor from its benefits.

78. 397 U.S. at 485 .

79. 402 U.S. at 143 (1971). 
Exclusionary zoning, however, raises considerations very different from those present in Dandridge and Valtierra. It is one thing to contend that the government does not have an obligation to provide welfare benefits or an adequate supply of low-income housing, but quite another to permit it. to depart from the neutrality of the free market and create special impediments to the construction of lowcost housing. Thus, exclusionary zoning presents a question much closer to Hunter $v$. Erickson ${ }^{80}$ _in which appellants requested that the government not impose special barriers against efforts to end private discrimination-than to Valtierra. Exclusionary zoning affects the right of the poor to purchase nonsubsidized as well as subsidized housing by denying permission to build low-cost housing within the zoned community. An attack on exclusionary zoning need not argue for remedial legislation, but only that the poor be allowed the same opportunity as others, namely noninterference with their right to build, buy, and rent housing within their means in the suburbs. The Court may be prepared to recognize the interest in housing as sufficiently fundamental and/or wealth classifications as sufficiently suspect to insist upon stringent judicial scrutiny of all impediments placed by the government in the path of private efforts to achieve an adequate supply of low-cost housing. ${ }^{81}$

\section{The Sliding Scale Constitutional Test}

Since Valtierra and Dandridge involved wealth classifications and a housing interest different from those present in exclusionary zoning statutes, ${ }^{82}$ these cases do not rule out the possibility that the combination of the wealth and racial classifications created and the housing interest affected by suburban zoning laws is sufficient to merit the imposition of the compelling state interest standard. ${ }^{83}$ The virtue of such an approach is that it permits the courts to subject to strict scrutiny those wealth and de facto racial classifications and those burdens on the interest in housing which have a significant cumulative invidious impact, without committing themselves to applying this rigorous standard in all cases where any one of these classifications or

80. 393 U.S. at 385 (1969).

81. One might also attempt to distinguish rallierra on the grounds that it was mainly concerned with the preservation of the right of people to use the democratic tool of referendum. It is not clear, however, why the court would give preference to discrimina. tory action approved by referendum over discriminatory action approved by state legislatures or city councils.

82. See pp. 73-81 supra.

83. See PP. 71-72 supra. 
interests can be detected. By applying the sliding scale approach coupled with an analysis of racial and wealth classifications and hous. ing interests such as that proposed above, ${ }^{84}$ the Court could restrict stringent review to those regulations, such as exclusionary zoning statutes, which most seriously inhibit social and economic mobility and deprive racial minorities and the poor access to such basic needs as decent housing and employment.

\section{Fashioning Relief}

Intervention in the area of exclusionary zoning is unlikely unless courts are convinced that effective and judicially manageable stanclards for granting relief exist. Clearly, remedies in the area of housing will turn on local circumstances, but general goals can be enunciated. First, fairness and urban realities indicate that remedies should trent low-cost housing as a metropolitan problem and should require that such housing be spread throughout metropolitan areas. Second, continued use of zoning for environmental and aesthetic purposes should be permitted as long as it does not prevent the poor from finding low-cost housing in the suburbs. ${ }^{85} \mathrm{~A}$ guideline which required every community in a metropolitan area to allow enough of its land to be zoned to absorb a share of the metropolitan area's low-cost housing approximately equal to its share of the total metropolitan housing would be a desirable way for courts to translate these perceptions into a workable remedy. Such a guideline would spread the burdens of a reduced per capita tax base throughout metropolitan areas yet would permit land-use planning consistent with aesthetic and environmental needs.

Although requests for variation from the guideline should require strong justification, downward variances should be permitted and upward variances ordered under certain circumstances. Variances from the guideline should be based upon the ability of a community to provide low-income residents with adequate public services and the means necessary for upward mobility, for example, good public education and proximity to job markets. Under no circumstances should a community be forced to open all its land to low-cost housing or be

84. See pp. 73-81 supra.

85. Zoning is the main land-planning tool, and courts will be hesitant to abolish it in the face of its great popularity and long use for aesthetic and environmental purposes. Indeed, as the issues of environment and land aesthetics are popularized, it becames more necessary than ever to demonstrate that the introduction of low-cost housing into at community need not do harm to either the aesthetics or the environment of a community. 
allowed to exclude such housing completely. Nearly every suburban community is able to provide some low-income families with the means necessary for social and economic advancement, ${ }^{80}$ and no community would find it fiscally possible to provide these means if it were populated only by very poor families.

No matter how conscientiously this guideline approach is followed, however, it is unlikely that such a remedy will suffice to cure the results of past exclusionary zoning practices. As pointed out above, ${ }^{87}$ exclusionary zoning has injured low-income families by artificially raising the price of land available for low-cost housing, thereby inhibiting the construction of such housing. Unfortunately, there are at least two reasons for expecting the adverse effects of exclusionary zoning to linger. First, there will probably be a considerable time lag between the elimination of exclusionary zoning and the impact of the "freed" market on artificially high property values. ${ }^{88}$ Second, land previously zoned to exclude low-income housing has generally been devoted to alternate uses over the years and will remain more expensive than it was prior to development. ${ }^{50}$ But a minimum standards approach, according to which the government would be compelled to provide everyone with adequate housing, seems unlikely to be adopted by the Supreme Court after Dandridge and Valtierra. ${ }^{00}$

Nonetheless, the minimum standards argument is not the only doctrinal means of imposing an obligation upon communities to help finance low-cost housing. Instead the Court might turn to the compensatory approach employed in Hobson $v$. Hansen, ${ }^{01}$ which ordered a wide range of measures to bring the Washington, D. C., school system back into the structural position it would have occupied had there been no history of unconstitutional discriminatory action favoring white middle-class students over black students. Similarly, in United States v. Plaquemines Parish Board of Education ${ }^{22}$ and United Stales v. Jefferson County Board of Education, ${ }^{03}$ school systems were ordered

86. As was pointed out in note 12 supra, the mere racial and cconomic integration of schools is beneficial to the children of low-income families, cren if the per student expenditure in integrated schools is no higher than in non-integrated schools.

87. See pp. 62-63 supra.

88. It will take builders a significant period of timc; they will have to acquire land and construct new buildings.

89. See, e.g., Regional Plan Association, Spread Crty 21-25 (1962).

90. See pp. 70-71, 80 supra.

91. 269 F. Supp, $401,514-18$ (D.D.C. 1967), aff'd sub nom. Smuck v. Hobson, 403 F.2d 175 (D.C. Cir. 1969).

92. 291 F. Supp. 841,846 (E.D. La. 1967).

93. 380 F.2d 385, 394 (5th Cir. 1967), cert. denied, 384 U.S. 1001 (1967). S.1SSO v. Union City, Civil No. 51590 (N.D. Cal,, July 30, 1970), can also be interpreted as imposing its remedy based on a compensation theory. 
to provide remedial programs for blacks who had been disadvantaged by inferior all-Negro schools. Analogously, there is little question that excessive cost of land and the low-cost housing shortage in the suburbs are largely a product of past discriminatory zoning practice. ${ }^{04}$ It seems just, therefore, that communities which have used unconstitutional means to deny decent housing to minorities should be required to bear the expense of compensatory housing programs designed to overcome the pernicious effects of past unconstitutional conduct. ${ }^{95}$ The sum of a community's compensatory obligation to build low-cost housing should be the amount of such housing which would have been built but for the community's exclusionary zoning policies. Although precise amounts may be difficult to calculate (as they are in the education area),$^{96}$ the alternative is to vindicate constitutional rights in form rather than substance, to permit the victims of past discriminatory conduct to continue to suffer at the hands of its perpetrators.

There are several methods of implementing the remedial principles outlined above. Under a community-by-community approach, localities would have two alternate ways of fulfilling their low-income housing obligations. Communities first would have the option of presenting a zoning plan which meets the guideline ${ }^{07}$ but also protects aesthetic and environmental interests. Such a plan would be required to place plots zoned for low-cost housing within a convenient distance of schools, major roads, shopping facilities, and other amenities. Of course, land zoned for low-cost high density housing should be capable of accommodating such buildings. For example, land zoned for such use in communities that use septic tanks rather than centralized sewage facilities must be able to absorb a large quantity of septic flow. The

94. See Note, Large Lot Zoning, 78 Yale L.J. 1418, 1421, 1427 n. 32 (1969).

95. It will of course be complicated to determine the amount which past discrimina. tion has cost the poor. However, there is precedent for a court's appointment of an outside expert to draw up a school desegregation plan. Swann v. Charlottc-Mecklenburs $306 \mathrm{~F}$. Supp. 1299, 1313 (1969). The federal rules provide for the appointment of a trial master. 5A J. Moore, Federal Practice 9 53.03, at 2921 (2d cd. 1971). A recent federal district court opinion ordered HUD to find housing-by building it if necessary-for blacks who had been forced out of their old homes by urban renewal prograins. Garictt v. City of Hamtramck, 40 U.S.L.W. 2361 (E.D. Mich. Nov. 22, 1971).

96. In the education compensation cases the courts did not even attempt to determine the exact amount of compensation necessary. Instead they ordered that compensatory programs be instituted to bring the level of achievement of the Black students up to that of the white students. See United States v. Plaquemines Parish School Bd., 291 F. Supp. 841, 846 (E.D. La. 1967), modified and as modified aff'd, 415 F.2d 817 (5th Cir. 1969); United States v. Jefferson County Bd. of Educ., 380 F.2d 385, 394 (5th Cir. 1967), cert. denied, 384 U.S. 1001 (1967).

97. Allowance would be made for variance from the guideline according to the com. munity's ability to provide its low-income residents with the tools necessary for upward mobility. See pp. $82-83$ supra. 
community would also be required to provide whatever financial subsidies might be necessary to construct the housing mandated as part of its compensatory obligation. If, on the other hand, a community fails to present an acceptable plan, it should be ordered to grant all requests for variances from existing zoning regulations for the building of lorv-cost housing and trailer parks, in the absence of extreme countervailing considerations, until its low-cost housing obligations are met. ${ }^{.8}$

For a variety of reasons courts would probably prefer a communityby-community approach. In some states exclusionary zoning may be present in only a few communities. In addition, zoning, like education, has traditionally been regarded as a local function. The community-bycommunity approach would keep responsibility for meeting constitutional standards in the hands of those local authorities responsible for exclusionary zoning. ${ }^{99}$ It would also permit courts to assess the effects of the remedy in a few communities before undertaking more massive intervention. Finally, an approach of this type might be the easiest to administer because it requires courts to immerse themselves in the complexities of only one community at a time.

Nevertheless, it may in some cases be advantageous to employ a state-wide remedy requiring the rezoning of the entire state to accommodate the needs for low-cost housing. Hawaii and Vermont, for example, have enacted zoning statutes which are administered and enforced by the state. ${ }^{100}$ In these cases it is clear that zoning is a state rather than local function and there is no need to fear conflict with traditional home rule powers. A state-wide remedy also has the advantage of focusing judicial and public attention on the fact that the housing needs of the poor are best dealt with by regional planning, thus taking into account the problems of employment and education without burdening particular communities with disproportionate responsibilities. In most states, however, zoning enabling acts delegate zoning authority to individual communities, and a state-wide remedy in these instances would conflict with community control over zoning. Such an approach would also be extremely difficult to administer, for it would require a judge to review the zoning practices

98. The court would also order the community to provide whatcrer finaneial assistance was required to meet its low-cost housing obligation.

99. A similar approach was taken in the school desegregation cases where courts acted against local school boards. See, e.g., Griffin v. County Sehool Bd., 377 U.S. 218 (1964); Brown v. Board of Educ., 349 U.S. 294 (1955).

100. See VT. Gen. Stat. tit. 10, $\$ \S 6001-6086$ (1971); Hawail Rev. Stat. $\$ \$ 305.1$ to -15 (1968). 
and consider the special circumstances of hundreds of communities simultaneously.

The third method, a metropolitan-wide remedy, has the important advantage of conforming especially closely to the realities of exclusionary zoning. Since the zoning policies of every community affect other communities and the metropolitan area as a whole, a remedy which would announce a metropolitan-wide approach to the low-cost housing problem is very attractive. Of course, some communities will object that their zoning powers are being seriously diluted. A remedy of this type, however, would interfere less with traditional home rule prerogatives than would the state-wide approach. More importantly, to the extent that low-cost housing presents a problem which can be fairly and effectively dealt with only on a metropolitan area level, 101 some limitations on the autonomy of individual communities appear to be both necessary and desirable. And to the extent that viable solutions to the racial and economic stratifications fostered by exclusionary zoning compel planning at the metropolitan level, this method of fashioning relief may be easier than dealing with individual towns in isolation. ${ }^{102}$

101. Failure to examine at least contiguous communities when deciding the appro. priateness of a community's new zoning statute may result in all of the low-income families of each community being zoned into adjoining neighborhoods, creating a ghetto of low-income housing. It is important that the new zoning provisions respond to metropolitan-wide job opportunities, traffic patterns, and location of public scrvices.

102. See Bradley v. School Bd., 40 U.S.L.W. 2446 (D.E. Va. Jan. 5, 1972) in which Richmond and two contiguous counties were required to adopt a metropolitan student assignment plan that would consolidate city and county school systems in order to achieve racial integration in the schools of the three political subdivisions. 